\title{
A Meta-summary of the Research on Metaphors Regarding Turkish EFL Teachers' Roles
}

\author{
Yusuf Demir* \\ School of Foreign Languages, Necmettin Erbakan University, Turkey
}

Corresponding Author: Yusuf Demir, E-mail: demir.ysf@ hotmail.com

\section{ARTICLE INFO}

Article history

Received: December 15, 2017

Accepted: February 26, 2018

Published: April 30, 2018

Volume: 9 Issue: 2

Advance access: March 2018

Conflicts of interest: None

Funding: None

\section{Key words:}

Metaphors,

EFL Teachers,

Teacher Roles,

Education,

Meta-summary

\begin{abstract}
This meta-summary set out to provide an overarching comprehension of the metaphorical conceptualizations with regard to Turkish EFL teachers' roles. Following the searches in a large number of international and national databases, and the setting of specific criteria for inclusion, eight research papers remained for investigation. The data analysis followed a theory-driven deductive approach to thematic analysis, by adopting the framework offered by Saban, Koçbeker and Saban (2006). After the transformation and standardization of the data sets in the related studies, it was found out that Turkish EFL teachers are most characterized by knowledge provider, and then facilitator/scaffolder roles. These are followed by nurturer/cultivator and archetype of spirit roles. Among the least associated roles with these teachers were superior authority figure, molder and agent of change. When intergroup differences of the perceptions are examined, the ELT student teachers and English learners conceptualized Turkish EFL teachers mainly as knowledge provider followed by facilitator/scaffolder, whereas the teachers tended to assign themselves the role of a facilitator/scaffolder most, followed by leader, knowledge provider, and entertainer.
\end{abstract}

\section{INTRODUCTION}

Originating from the Latin word metaphora which means carrying over, metaphors are a means of understanding and experiencing one concept in terms of another, and they form the way we think, experience and act every day (Lakoff \& Johnson, 1980). With this in mind, metaphors are not only a linguistic tool or a figure of speech. Having theoretical underpinnings deeply rooted in cognitive linguistics, metaphor "provides a systematic guide to the cognitive and affective dimensions of our sense of self" as well as "...explanatory foundations for conceptual systems and language in the general study of the brain and the mind" (Lakoff \& Johnson, 2003, p. 270). From this point forth, by bringing a depth of vocabulary to describing experiences, metaphors build on the relationship between language and thought (Munby \& Russell, 1990), and bridge between cognition and communication (Ortony \& Fainsilber, 1989). Through their function of expressing abstract concepts with more concrete images (Oxford, et al., 1998), metaphors help us structure our understanding of events (Perry \& Cooper, 2001), people and the world.

Teachers are not an exception for the prevalent use of metaphor as a cognitive tool (Guerrero \& Villamil, 2000). Metaphors have widely been used in educational research so as to reveal personal theories and underlying beliefs of and concerning teachers, elucidate and position their teaching practices. Elicitation of the main teaching roles this way leads to potential reflective practices and instructional changes (Tobin, 1990). In addition, the uncovering of teachers' roles through metaphors helps them process the analysis and planning of teaching, think deeply about teaching and learning (Martinez, Sauleda \& Huber, 2001), and better understand the contextual dynamics as well as their students' expectations from them. More contributions of metaphors to teaching and teachers are collocated by Botha (2009), such as helping decision-making for educational policies, determining the way the learner or learning process is viewed, promoting the teacher's professional growth, and so on. Given all these virtues available, teachers' roles through the analysis of metaphors have been revealed in a plethora of studies with the inclusion of students, pre-service teachers and teachers themselves with regard to different subjects (Fleener, 1995; Saban et al., 2006; Seferoğlu, Korkmazgil \& Ölçü, 2009; Sumsion, 2003; Hamilton, 2016). Likewise, in foreign language learning and teaching field too, metaphors have amply been used to elicit metaphors about EFL learners, learning and teaching (Şimşek, 2014; Erkmen, 2010; Fang, 2015; Coşkun, 2015; Çelik \& Asmal1, 2017; Elkılıç \& Aybirdi, 2016; Özcan, Koçyiğit \& Erdem, 2017), language learning process (Baş \& Gezegin, 2015), foreign language classroom (İnceçay, 2015), ELT coursebooks (Kesen, 2010; 
Şimşek \& Dündar, 2015), speaking English (Dinçer, 2017), and most commonly about EFL teachers (Wan, Low \& Li, 2011; Nikitina \& Furuoka, 2008; Akbari, 2013; Oktay \& Osam, 2013; Jitpranee, 2017; Tercan, 2015).

Drawing a local portrait for the present research context, the studies on metaphorical conceptualizations of Turkish EFL teachers lack unity in terms of the emergent metaphorical roles. For example, while in some studies EFL teachers' knowledge provider roles were featured (Kavanoz, 2016; Yalçın-Arslan \& Cinkara, 2016), in some others, they were mainly identified through their roles as a guide (Yeşilbursa, 2012; Sayar, 2014). Each metaphor, and by extension, each study of metaphor can communicate only a part of the complexity of the phenomenon and classroom realities (Marshall, 1990). For this reason, it is necessary to carry out collective meta-studies which can synthesize the research on the same topic in order to help to make integrative and well-grounded interpretations (Çalık \& Sözbilir, 2014). To these ends, this study conducts a meta-summary of the available research findings on metaphorical role conceptualizations toward Turkish EFL teachers as perceived by the teachers themselves, student teachers and learners. With such a perspective, the following research questions are investigated:

1. How are Turkish EFL teachers' roles conceptualized metaphorically in a cumulative sense?

2. Do EFL teachers, student teachers and learners conceptualize the roles of Turkish EFL teachers differently?

\section{RESEARCH DESIGN}

This study is a qualitative meta-summary of the related research findings on metaphorical conceptions concerning Turkish EFL teachers' roles and identities. The methodological underpinning of the present study derives from Sandelowski and Barroso's (2007) qualitative research synthesis specifications that define qualitative metasummary as "a quantitatively oriented aggregation of qualitative research findings that are themselves topical or thematic summaries or surveys of data" (p. 17). Metasummary is optimally performed in cases when the qualitative findings to be integrated are judged to be summaries of qualitative data rather than interpretive synthesis. This methodological approach to synthesizing qualitative research can include qualitative and quantitative descriptive findings, and allows for the identification of the frequency of individual findings (Sandelowski, Barroso \& Voils, 2007). This study adopts qualitative meta-summary methodology due to the fact that the findings of the studies in focus are at the topical/thematic level (i.e. metaphors for English language teachers and their roles) rather than having an interpretive nature, and therefore, can be better understood through quantitative tabulations and graphical representations. This study employs in its different phases the techniques used in qualitative meta-summaries by extracting and separating findings from other elements of the research report, editing and grouping findings in common topical domains, and calculating descriptive measures as a quantitative transformation of qualitative data in an effort to derive more meaning from the data (Sandelowski et al., 2007).

\section{Procedure for Obtaining the Relevant Studies}

The articles for this meta-summary were obtained through the searches in the following international and national research databases: Web of Science, Educational Resources Information Center (ERIC), Scopus, EBSCOhost Research Databases, ProQuest, Directory of Open Access Journals (DOAJ), Turkish Academic Network and Information Center (ULAKBIM), Academia Social Science Index (ASOS), Turkish Education Index, Turkish Higher Education Council's thesis database. The keyword-based searches included terms such as [metaphor(s), education], [(English) teacher, metaphor(s)], [English, metaphor(s)], [conceptual metaphor]. The initial search was conducted in the first two weeks of February 2017. A second complementary search was run through the same databases on November 3-4 the same year, for potential newly emergent publications. The process generated an initial repository of 32 studies.

\section{Criteria for Study Selection}

First and foremost, in order to ensure quality standards for the studies used in this meta-summary, articles in peer-reviewed journals and post-graduate theses were included whereas conference abstracts and full papers published in conference proceedings were removed from the initial repository. This is because "most qualitative syntheses use studies from peer-reviewed journals, since these have been subjected to peer review and thus have at least one layer of quality control built in" (Major \& Savin-Baden, 2010, p. 48-49). After this sifting process, the following criteria were then applied for inclusion: the research setting needed to be Turkey even if it sampled Turkish EFL teachers (e.g. Oktay \& Osam (2013) was removed for potential cultural effects and orientations). In addition, the studies needed to embody metaphors that focus on Turkish EFL teachers' educational roles only. Studies on metaphors for teachers in general (e.g. Seferoğlu, Korkmazgil \& Ölçü; 2009), learning English (e.g. Coşkun, 2015), the English and English culture (e.g. Şahin, Seçer \& Erişen, 2016), EFL learners (e.g. Elkılıç \& Aybirdi, 2016) and learning environment (e.g. İnceçay, 2015), and ELT coursebooks (e.g. Şimşek \& Dündar, 2015) were eliminated. Alongside these studies, Şimşek (2014) was also removed from the initial repository because it elicited pre- and post-metaphors following a purposeful course intervention.

Application of the above criteria led to the selection of eight core studies comprising the final data set. Arising from the controlling factors and purposeful selection of the studies which complied with the rationale for this investigation (Brown \& Lan, 2015), this number seems to be optimal in terms of sufficiency and manageability (Major \& SavinBaden, 2010).

\section{The Data Set}

As Shown in Figure 1 below, all the core studies were published in the last decade. This leads to the inference that the study of metaphors concerning Turkish EFL teachers' roles has gained momentum only recently in the present research context. 
As can be seen in Table 1 , the core studies elicited metaphors for Turkish EFL teachers from three groups of participants: EFL teachers themselves, student teachers and learners. While four of the studies collected data only through metaphor elicitation tasks (e.g. An English teacher is like ... because ...), the three other studies reinforced elicitation tasks with interviews, personal essays and diaries, and the remaining one made use of an essay only.

Table 1. The studies under scrutiny

Figure 1: The Distribution of the Studies across Years

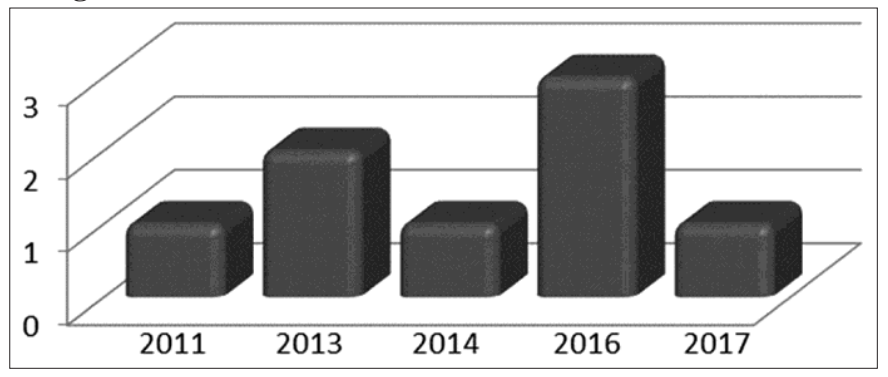

\begin{tabular}{lll}
\hline Paper ID & The study & Research sample \\
\hline I & $\begin{array}{l}\text { Yalçın-Arslan } \\
\text { \& Cinkara (2016) }\end{array}$ & $\begin{array}{l}102 \text { ELT student } \\
\text { teachers }\end{array}$ \\
& & \\
II & Sayar (2014) & $\begin{array}{l}10 \text { EFL teachers \& } \\
\text { 200 tertiary-level } \\
\text { English language } \\
\text { learners }\end{array}$ \\
& &
\end{tabular}

III

Asmal1 \&

Çelik (2017)

IV

Elkılıç \&

Bayrakçı (2016)

V

Kavanoz (2016)

\section{Research questions/purposes}

1. What are the metaphors of pre-service EFL teachers about being a language teacher? 2. What are the lexical categories used in the host statements of metaphors?

1. What metaphors do EFL teachers use to represent themselves?

2. What metaphors do EFL teachers' students use to represent their teachers?

3. What conceptual categories can be drawn from these metaphorical images?

4. To what extent do individual metaphorical accounts of perceptions of EFL teachers' roles differentiate between teachers and their students?

5. How do teachers respond to metaphorical expressions proposed by their students?

24 EFL teachers

65 Translation and Interpretation students

94 ELT student teachers

50 ELT student teachers \& 50 English language learners

One EFL teacher
How do EFL teachers conceptualize their roles through metaphors?

1. What are the metaphors used by Turkish translation and interpretation students in relation to their English/French language instructors? 2. How many conceptual categories can be determined in accordance with the metaphors created by Turkish translation and interpretation students in relation to their English/French language instructors?

1. What metaphors do Turkish pre-service language teachers generate to describe teachers of English?

2. What differences can be observed in the metaphors chosen by pre-service EFL teachers in terms of their year level?

1- What are the conceptual metaphors of ELT major learners in regard to their perception of an English language teacher? 2- What are the conceptual metaphors of non-ELT major learners in regard to their perception of an English language teacher? 3- What are the similarities and/or discrepancies between ELT major learners and non-ELT major learners in their perception of an English language teacher?

The study aims to elicit the beliefs of a language teacher at two different periods of time.
Data collection tool

Essay (What do you think about what a language teacher is like?)

Semi-structured interviews (with the teachers) \& My teacher is like ... because ... (for the students)

An English teacher is like ... because...

English language instructors are like ... because they ...

An EFL teacher is like...because...

Metaphor elicitation sheet $(A n$ English language teacher is al an ..., + reasons), Semi-structured interviews \& Personal essays

A teacher is ... because ..., Interviews \& Diaries

Teaching a language is like ... because ... 


\section{Data Analysis, Transformation and Standardization}

The data from the core studies in this meta-summary were analyzed through a descriptive and deductive approach to thematic analysis. For, such an analysis is theory-driven, led by the researcher's specific thematic interest (Halland, 2007), and draws on some form of template, developing out the relevant literature so as to code the data and derive themes from it (Willig, 2013).

Table 2. Top emergent categories regarding Turkish EFL teachers' roles in the related studies (before the standardization)

\begin{tabular}{|c|c|c|c|}
\hline Paper ID & Top emergent categories & $\begin{array}{l}\text { Total occurrences } \\
\text { (total metaphor } \\
\text { occurrences that } \\
\text { represent the related } \\
\text { category-reoccurrences } \\
\text { included) }\end{array}$ & Percentage $(\%)$ \\
\hline \multirow[t]{5}{*}{ I } & Knowledge provider & 25 & 25 \\
\hline & Facilitator/scaffolder & 23 & 23 \\
\hline & Archetype of spirit & 20 & 20 \\
\hline & Nurturer/cultivator & 16 & 16 \\
\hline & Molder/craftperson & 15 & 15 \\
\hline Total & & 99 & 100 \\
\hline \multirow[t]{5}{*}{ II } & Guide & 30 & 25 \\
\hline & Nurturer & 28 & 23 \\
\hline & Expert & 27 & 23 \\
\hline & Knowledge provider & 21 & 18 \\
\hline & Authority & 13 & 11 \\
\hline Total & & 119 & 100 \\
\hline \multirow[t]{5}{*}{ III } & Knowledge provider & 17 & 33 \\
\hline & Nurturer & 12 & 23 \\
\hline & Cooperative leader & 11 & 22 \\
\hline & Artist & 6 & 12 \\
\hline & Challenger/Agent of change & 5 & 10 \\
\hline Total & & 51 & 100 \\
\hline \multirow[t]{6}{*}{ IV } & Source of information or guide & 17 & 32 \\
\hline & A significant other & 14 & 27 \\
\hline & Caring or shaping & 7 & 14 \\
\hline & Monotonous Object/Person & 5 & 9 \\
\hline & Animal & 5 & 9 \\
\hline & Somebody disliked & 5 & 9 \\
\hline Total & & 53 & 100 \\
\hline \multirow[t]{5}{*}{ V } & Source and provider of knowledge & 32 & 46 \\
\hline & Cooperative leader & 11 & 15 \\
\hline & Direction setter & 11 & 15 \\
\hline & Facilitator & 10 & 15 \\
\hline & Entertainer & 6 & 9 \\
\hline Total & & 70 & 100 \\
\hline \multirow[t]{5}{*}{ VI } & Illuminator & 17 & 39 \\
\hline & Source of knowledge & 9 & 20 \\
\hline & Provider of communication & 7 & 16 \\
\hline & Guide & 6 & 14 \\
\hline & Decision maker & 5 & 11 \\
\hline Total & & 44 & 100 \\
\hline
\end{tabular}

With such a perspective, the researcher classified and transformed the metaphorical categorical data based on the framework offered by Saban et. al. (2006). Table 2 provides the initial metaphor categories regarding Turkish EFL teachers' roles as classified by the authors themselves before the data were transformed and standardized. 
Table 2. (Continued)

\begin{tabular}{|c|c|c|c|}
\hline Paper ID & Top emergent categories & $\begin{array}{c}\text { Total occurrences } \\
\text { (total metaphor } \\
\text { occurrences that } \\
\text { represent the related } \\
\text { category-reoccurrences } \\
\text { included) }\end{array}$ & Percentage $(\%)$ \\
\hline \multirow[t]{5}{*}{ VII } & Facilitator & 8 & 38 \\
\hline & Producer & 4 & 19 \\
\hline & Guide & 4 & 19 \\
\hline & Leader & 3 & 14 \\
\hline & Resource & 2 & 10 \\
\hline Total & & 21 & 100 \\
\hline \multirow[t]{9}{*}{ VIII } & Actor/Actress & 7 & 28 \\
\hline & Cooperative leader & 4 & 16 \\
\hline & Provider of knowledge & 2 & 8 \\
\hline & Artist & 2 & 8 \\
\hline & Innovator & 2 & 8 \\
\hline & Guide & 2 & 8 \\
\hline & Nurturer & 2 & 8 \\
\hline & Construction engineer & 2 & 8 \\
\hline & Guru & 2 & 8 \\
\hline Total & & 25 & 100 \\
\hline
\end{tabular}

\footnotetext{
*The content of the table was reported only based on the categories set by their respective authors.

*The percentages were distributed only among the top five emergent categories in the studies. In cases when there was more than one fifth ranker, they were allincluded (e.g . study IV and VIII),

*In the listing of the categories in Study VII, those that occurred most frequently within 24-month period of change were included,

*Teacher-generated metaphors in Study II were excluded since they were not categorized by the author,

*Study VI collected metaphors from both ELT student teachers and university-level EFL learners, which came up with two different conceptual categorical data sets. To serve the purpose of the study, the cumulative top five emergent categories were considered: two from the ELT student teachers, three from the EFL learners. Since Illumination category was available in both, the occurrences were added up $(11+6=17)$,

*As different from the other studies, in Study IV, two negative conceptual categories emerged (English language instructor as a monotonous object/person and as somebody disliked). However, given the focus of the study which relates to English language teachers' roles, these negative categories were not included in the analyses. In addition, since metaphors under teacher as animal category were concerned with teachers' school routines rather than their roles (e.g. An English language instructor is like a migratory bird because he/she should teach language travelling from one class to another one), they were excluded during standardization process.
}

The categorization of the metaphorical conceptualizations of the studies, as shown above, drew on several frameworks. While some of them adopted that of Saban et. al. (2006), some others drew from Oxford et. al. (1998) or generated their own categorizations. Therefore, the need arose for a categorical standardization in order to make possible holistic, systematic and well-grounded analyses.
To this end, being an extensive and overarching one, the categories in these studies were standardized and reported based on the main conceptual themes/categories specified by Saban et. al. (2006). Table 3 accounts for and justifies through which criteria the emergent metaphors were embedded in a particular category in Saban et. al. (2006), and, by extension, in the categorical standardization process of the current study. 
Table 3. Operational definitions for the conceptual categories (adapted from Saban et al., 2006)

Teacher as knowledge provider

Teacher as molder/craftsperson

Teacher as curer/repairer

Teacher as superior authority figure

Teacher as change agent

Teacher as entertainer

Teacher as archetype of spirit

Teacher as nurturer/cultivator

Teacher as facilitator/scaffolder

Teacher as cooperative/democratic leader
The teacher is the source and the transmitter of knowledge. Teaching is the act of delivering knowledge and skills, while learning entails the accumulation of the teacher's knowledge.

The student is the raw material, and the teacher is responsible for bringing up students as socially useful products and shaping them into a prescribed mold.

The student is in need of intellectual and behavioral repair. The teacher diagnoses and treats students' illnesses, flaws, and/or deficiencies.

The teacher has the authority to control classroom variables and decides on what and how to teach. The students have to obey their teachers and submit to authority.

The teacher acts as a social agent and tries to design a new social culture by changing students' mindsets.

Learning should be fun and enjoyable for students.

As a role model, the teacher helps students develop a good character and cares about each student's psychological and emotional wellbeing.

The teacher should attend to the individual needs and interests of the students and support the growth of each student.

The teacher acts as a guide in the teaching-learning process and facilitates learning. Students construct their own knowledge in this process.

The teacher is a cooperative/democratic leader. He/she works together with the students, not in isolation from them.
In the light of the operational definitions above, the categorical transformations made during the standardization process are provided below:

1- The teacher as guide category which was available in some of the studies was standardized as Saban et. al.'s (2006) teacher as facilitator/scaffolder category. This was because the teacher under this labeling was defined in the same study as a guide in teaching-learning process.

2- In study VI, teacher as decision maker was replaced by teacher as superior authority figure due to the fact that "for the participants creating these metaphors, referee, manager, judge, policeman, and boss best represent an English language teacher as they are considered authoritative figures (Ahkemoğlu, 2011, p. 36)". Moreover, illumination category emergent in the same study was transformed into teacher as knowledge provider given the participants' clarifications that "the language teacher sheds light on them with his knowledge of the foreign language" (p. 40). In a similar vein, teacher as expert $(n=27)$ category emergent in Study II was changed to teacher as knowledge provider. This was because the author defined teacher as expert as the source of information who knows everything about language learning and teaching (Sayar, 2014).

3- Teacher as source of knowledge, source of information, resource categories were changed to teacher as knowledge provider owing to definitional uniformity.
4- Teacher as significant other in study IV was categorized as teacher as archetype of spirit given the definitional uniformity of both categories. Teacher as somebody caring or shaping $(n=7)$ that emerged in the same study was divided among teacher as nurturer/cultivator $(\mathrm{n}=2)$, teacher as knowledge provider $(\mathrm{n}=3)$, and teacher as molder/craftsperson $(n=2)$; while teacher as source of information or guide $(\mathrm{n}=17)$ was distributed to teacher as knowledge provider $(\mathrm{n}=11)$, teacher as facilitator/scaffolder $(n=4)$, and teacher as superior authority figure $(n=2)$ categories following one-by-one metaphorical investigation. Likewise, teacher as producer $(n=4)$ in Study VII was divided among teacher as change agent $(n=2)$, teacher as superior authority figure $(n=1)$, and teacher as entertainer $(n=1)$ categories.

5- Teacher as direction setter in Study V was converted to teacher as facilitator/scaffolder, since the author defined the teacher of this category as the person who leads "students towards their goals and helps them reach the unknown..." (Kavanoz, 2016, p. 23) with the metaphors of light house, compass etc. just as in Saban et. al. (2006) for the same grounds.

6- Other standardization moves included the transformation of teacher as artist in study III to teacher as entertainer; teacher as artist in study VIII to teacher as molder/craftsperson, teacher as actor/actress to teacher as 
entertainer, teacher as innovator to teacher as change agent, teacher as guru to teacher as archetype of spirit, and teacher as construction engineer to teacher as molder/craftsperson. All the categorical modifications and transformations made for the categorical standardization were grounded upon the abovementioned operational definitions as well as metaphor generators' justifications for each metaphor.
Right after the researcher finished the standardization task, as a technique to establish credibility and trustworthiness (Spall, 1998; Creswell \& Poth, 2017), peer debriefing was applied to the whole standardization procedure to serve as "an external check on the inquiry process" (Lincoln \& Guba, 1985, p. 301). The peer debriefer colleague was trained on the conceptual metaphor categories and operational definitions first, which culminated in her confirmation of the transformed and standardized categories in the course of a one-time two-hour-long meeting. Table 4 shows the featured metaphor categories after the standardization.

\section{RESULTS}

\section{Metaphorical Conceptualizations of Turkish EFL Teachers' Roles}

Table 4. Top emergent categories regarding Turkish EFL teachers' roles in the related studies (after the standardization)

\begin{tabular}{|c|c|c|c|}
\hline Paper ID & Top emergent categories & $\begin{array}{l}\quad \text { Total occurrences } \\
\text { (total metaphor occurrences that } \\
\text { represent the related category- } \\
\text { reoccurrences included) }\end{array}$ & $\begin{array}{c}\text { Percentage } \\
(\%)\end{array}$ \\
\hline \multirow[t]{5}{*}{1} & Knowledge provider & 25 & 25 \\
\hline & Facilitator/scaffolder & 23 & 23 \\
\hline & Archetype of spirit & 20 & 20 \\
\hline & Nurturer/cultivator & 16 & 16 \\
\hline & Molder/craftperson & 15 & 15 \\
\hline Total & & 99 & 100 \\
\hline \multirow[t]{4}{*}{2} & Knowledge provider & 48 & 40 \\
\hline & Facilitator/scaffolder & 30 & 25 \\
\hline & Nurturer/cultivator & 28 & 24 \\
\hline & Superior authority figure & 13 & 11 \\
\hline Total & & 119 & 100 \\
\hline \multirow[t]{5}{*}{3} & Knowledge provider & 17 & 33 \\
\hline & Nurturer/cultivator & 12 & 23 \\
\hline & Coop./democratic leader & 11 & 22 \\
\hline & Entertainer & 6 & 12 \\
\hline & Agent of change & 5 & 10 \\
\hline Total & & 51 & 100 \\
\hline \multirow[t]{6}{*}{4} & Knowledge provider & 14 & 37 \\
\hline & Archetype of spirit & 14 & 37 \\
\hline & Facilitator/scaffolder & 4 & 11 \\
\hline & Superior authority figure & 2 & 5 \\
\hline & Molder/craftperson & 2 & 5 \\
\hline & Nurturer/cultivator & 2 & 5 \\
\hline Total & & 38 & 100 \\
\hline \multirow[t]{4}{*}{5} & Knowledge provider & 32 & 46 \\
\hline & Facilitator/scaffolder & 21 & 30 \\
\hline & Coop./democratic leader & 11 & 16 \\
\hline & Entertainer & 6 & 8 \\
\hline Total & & 70 & 100 \\
\hline \multirow[t]{3}{*}{6} & Knowledge provider & 26 & 59 \\
\hline & Facilitator/scaffolder & 13 & 30 \\
\hline & Superior authority figure & 5 & 11 \\
\hline Total & & 44 & 100 \\
\hline
\end{tabular}


Table 4. (Continued)

\begin{tabular}{|c|c|c|c|}
\hline Paper ID & Top emergent categories & $\begin{array}{c}\text { Total occurrences (total } \\
\text { metaphor occurrences that } \\
\text { represent the related } \\
\text { category-reoccurences } \\
\text { included) } \\
\end{array}$ & Percentage $(\%)$ \\
\hline \multirow[t]{6}{*}{7} & Facilitator/scaffolder & 12 & 56 \\
\hline & Coop./democratic leader & 3 & 14 \\
\hline & Knowledge provider & 2 & 10 \\
\hline & Agent of change & 2 & 10 \\
\hline & Entertainer & 1 & 5 \\
\hline & Superior authority figure & 1 & 5 \\
\hline Total & & 21 & 100 \\
\hline \multirow[t]{8}{*}{8} & Entertainer & 7 & 28 \\
\hline & Coop./democratic leader & 4 & 16 \\
\hline & Molder/craftperson & 4 & 16 \\
\hline & Knowledge provider & 2 & 8 \\
\hline & Agent of change & 2 & 8 \\
\hline & Facilitator/scaffolder & 2 & 8 \\
\hline & Nurturer/cultivator & 2 & 8 \\
\hline & Archetype of spirit & 2 & 8 \\
\hline Total & & 25 & $100 \%$ \\
\hline
\end{tabular}

Table 4 takes an eagle's eye view of the studies one by one, portraying the top emergent categories in the studies, total metaphor occurrences representing them, and categorical percentages within each study. Yet, in the course of reporting the most commonly occurring categories, it would be misleading only to consider the total occurrences or percentages (For, the research samples of the studies comprise different numbers of participants which would directly affect the potential number of emergent metaphors. Moreover, small number of occurrences could have generated big percentages).
These descriptors might fall short in specifying prominent categories in a summative manner, and thus in providing a sound understanding of the teachers' conceptual roles. For this reason, it was apt to give more descriptive information regarding the categories individually. In Table 5, by comparing each conceptual category against the others emergent in the same study and those in the other studies, and considering the (frequencies of) emergence, mean percentages, total occurrences and ranking of each category within all the studies in a holistic manner, the following categories are highlighted, in a descending order, as the most common conceptual categories that define the roles of EFL teachers.

Table 5. Descriptive information regarding each emergent category

\begin{tabular}{|c|c|c|c|c|}
\hline $\begin{array}{l}\text { Conceptual } \\
\text { metaphor category }\end{array}$ & $\begin{array}{c}\text { Emergence } \\
\text { frequency (out } \\
\text { of } 8 \text { studies) }\end{array}$ & $\begin{array}{l}\text { Featured } \\
\text { rankings }\end{array}$ & $\begin{array}{c}\text { Mean } \\
\text { percentage (Percentage } \\
\text { totals of the related } \\
\text { category in the studies } \\
\text { it emerged/emergence } \\
\text { frequency) }(\%)\end{array}$ & $\begin{array}{c}\text { Total occurrences } \\
\text { (total metaphor } \\
\text { occurrences that } \\
\text { represent the related } \\
\text { Category reoccurrences } \\
\text { included) }\end{array}$ \\
\hline Knowledge provider & 8 & $\begin{array}{l}\# 1 \text { in } 6 \text { studies } \\
\# 1 \text { in total } \\
\text { occurences } \\
\# 1 \text { in mean } \\
\text { percentage }\end{array}$ & 32 & 166 \\
\hline Facilitator/scaffolder & 7 & $\begin{array}{l}\# 1 \text { in } 1 \text { study } \\
\text { \#2 in } 4 \text { studies }\end{array}$ & 26 & 105 \\
\hline Nurturer/cultivator & 5 & $\begin{array}{l}\text { \#2 in } 1 \text { study } \\
\text { \#last in } 2 \text { studies }\end{array}$ & 15 & 60 \\
\hline Archetype of spirit & 3 & $\begin{array}{l}\text { \#1 in } 1 \text { study } \\
\text { \#last in } 1 \text { study }\end{array}$ & 22 & 36 \\
\hline
\end{tabular}


Table 5. (Continued)

\begin{tabular}{|c|c|c|c|c|}
\hline $\begin{array}{l}\text { Conceptual } \\
\text { metaphor category }\end{array}$ & $\begin{array}{c}\text { Emergence } \\
\text { frequency (out } \\
\text { of } 8 \text { studies) }\end{array}$ & $\begin{array}{l}\text { Featured } \\
\text { rankings }\end{array}$ & $\begin{array}{c}\text { Mean } \\
\text { percentage (Percentage } \\
\text { totals of the related } \\
\text { category in the studies } \\
\text { it emerged/emergence } \\
\text { frequency) }(\%)\end{array}$ & $\begin{array}{l}\text { Total occurrences } \\
\text { (total metaphor } \\
\text { occurrences that } \\
\text { represent the related } \\
\text { Category-reoccurrences } \\
\text { included) }\end{array}$ \\
\hline Entertainer & 4 & $\begin{array}{l}\text { \#1 in } 1 \text { study } \\
\text { \#last in } 2 \text { studies }\end{array}$ & 13 & 20 \\
\hline $\begin{array}{l}\text { Cooperative/ } \\
\text { democratic leader }\end{array}$ & 4 & $\# 2$ in 2 studies & 7 & 29 \\
\hline Molder/craftperson & 3 & \#last in 2 studies & 12 & 21 \\
\hline $\begin{array}{l}\text { Superior authority } \\
\text { figure }\end{array}$ & 4 & $\begin{array}{l}\text { \#last in all the } \\
\text { four studies }\end{array}$ & 5 & 21 \\
\hline & & $\begin{array}{l}\text { \#last in mean } \\
\text { Percentage }\end{array}$ & & \\
\hline Agent of change & 3 & $\begin{array}{l}\text { \#last in } 2 \\
\text { studies } \\
\text { \#last in total } \\
\text { occurences }\end{array}$ & 9 & 9 \\
\hline
\end{tabular}

Based on the information shown in Table 5, Figure 2 is provided for a more perceptible portrayal of the emergent categories regarding the teachers' roles. Just as in the categorical standardization process, peer debriefing was provided by the same colleague to arrive at common understanding of the extent of categorical representations and illustrations.

As can be inferred from Table 5 and Figure 2, the teachers are most defined and conceptualized in terms of their knowledge provider, and then facilitator/scaffolder roles. These are followed by nurturer/cultivator and archetype of spirit role perceptions. Superior authority figure, molder and agent of change seem to be the least metaphorically conceptualized roles that relate to Turkish EFL teachers.

Conceptualization of Turkish EFL Teachers' Roles as Perceived by EFL Teachers, Student Teachers and Learners

Table 6 demonstrates the metaphorical conceptualizations of the teachers' roles as perceived by the EFL teachers, student teachers and learners. All the emergent categories in the related studies (based on participant groups) are listed as well as which categories are common in these studies. In addition, featured rankings, mean percentages and total occurrences are provided.
Figure 2: Emergent categories regarding Turkish EFL teachers' roles

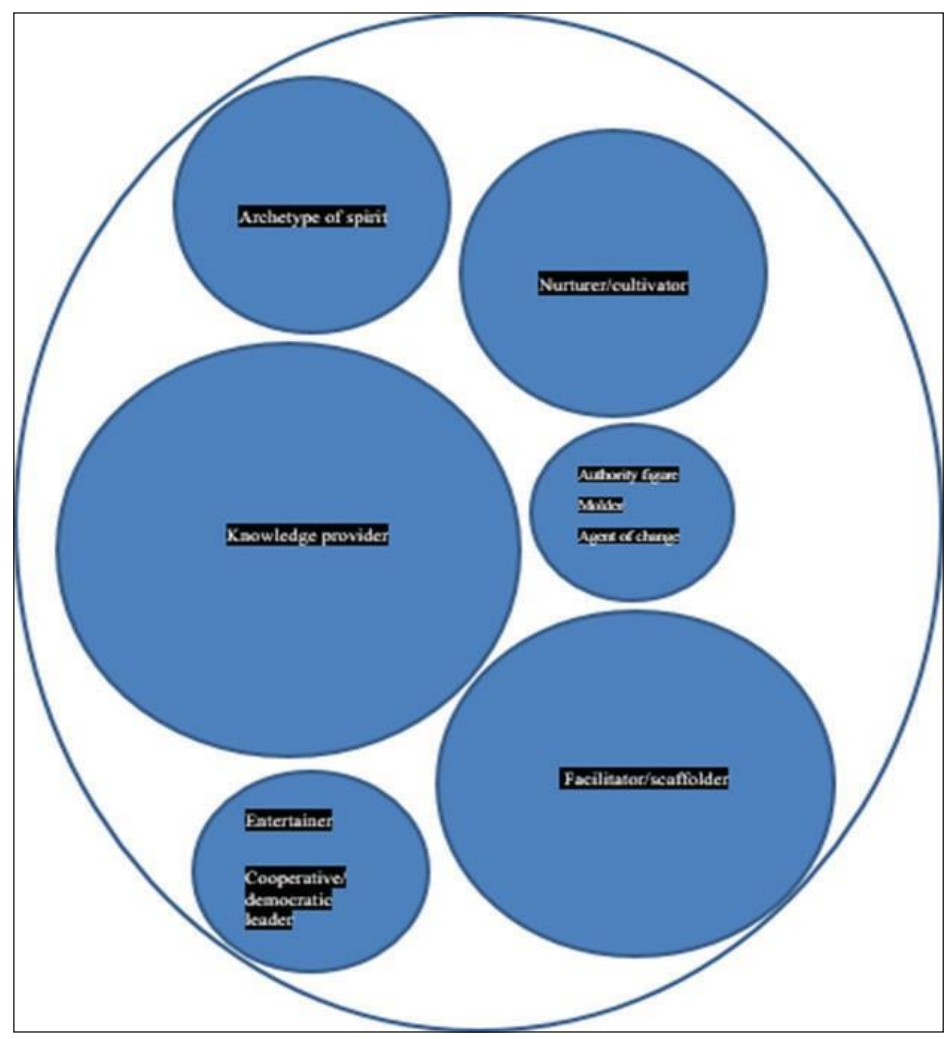


Table 6. Descriptive information about the conceptual categories regarding EFL teachers' roles from the point of the teachers, student teachers and learners

\begin{tabular}{|c|c|c|c|c|c|}
\hline & $\begin{array}{l}\text { All the } \\
\text { emergent } \\
\text { categories }\end{array}$ & $\begin{array}{l}\text { Common } \\
\text { categories } \\
\text { emergent in the } \\
\text { related studies }\end{array}$ & $\begin{array}{l}\text { Mean } \\
\text { percentage (Percentage } \\
\text { totals of the related } \\
\text { category in the studies } \\
\text { it emerged/emergence } \\
\text { frequency) }(\%)\end{array}$ & $\begin{array}{l}\text { Total occurrences } \\
\text { (total metaphor } \\
\text { occurrences that } \\
\text { represent the related } \\
\text { category -reoccurences } \\
\text { included) }\end{array}$ & $\begin{array}{l}\text { Featured } \\
\text { rankings }\end{array}$ \\
\hline $\begin{array}{l}\text { Teachers } \\
\text { (Study III, } \\
\text { VII and } \\
\text { VIII) }\end{array}$ & $\begin{array}{l}\text { 1.Coop./democratic } \\
\text { leader } \\
\text { 2.Molder/craftperson } \\
\text { 3.Knowledge provider } \\
\text { 4.Agent of change } \\
\text { 5.Facilitator/scaffolder } \\
\text { 6.Nurturer/cultivator } \\
\text { 7.Entertainer } \\
\text { 8.Archetype of spirit } \\
\text { 9.Sup. authority figure }\end{array}$ & $\begin{array}{l}\text { 1. Knowledge } \\
\text { provider } \\
\text { 2. Entertainer } \\
\text { 3. Coop./ } \\
\text { democratic leader } \\
\text { 4. Agent of } \\
\text { change }\end{array}$ & $\begin{array}{l}\text { Facilitator/scaffol. (32) } \\
\text { Coop./dem. leader (17) } \\
\text { Knowled. provider (17) } \\
\text { Entertainer (15) } \\
\text { Nurturer/cultivator (16) } \\
\text { Agent of change (9) }\end{array}$ & $\begin{array}{l}64 \\
52 \\
51 \\
45 \\
31 \\
28\end{array}$ & $\begin{array}{l}\# 1 \text { in } 1 \text { study } \\
\# 2 \text { in } 2 \text { studies } \\
\# 2 \text { in } 1 \text { study } \\
\# 1 \text { in } 1 \text { study } \\
\# 1 \text { in } 1 \text { study } \\
-\end{array}$ \\
\hline $\begin{array}{l}\text { Student } \\
\text { teachers } \\
\text { (Study I, V } \\
\text { and VI) }\end{array}$ & $\begin{array}{l}\text { 1.Coop./democratic } \\
\text { leader } \\
\text { 2.Molder/craftperson } \\
\text { 3.Knowledge provider } \\
\text { 4.Facilitator/scaffolder } \\
\text { 5.Nurturer/cultivator } \\
\text { 6.Entertainer } \\
\text { 7.Archetype of spirit } \\
\text { 8.Sup. authority figure }\end{array}$ & $\begin{array}{l}\text { 1. Knowledge } \\
\text { provider }\end{array}$ & $\begin{array}{l}\text { Knowled. provider (30) } \\
\text { Facilitator/scaffol. (27) }\end{array}$ & $\begin{array}{l}91 \\
53\end{array}$ & $\begin{array}{l}\# 1 \text { in } 3 \text { studies } \\
\# 2 \text { in } 2 \text { studies }\end{array}$ \\
\hline $\begin{array}{l}\text { Learners } \\
\text { (Study II, } \\
\text { IV and } \\
\text { VI) }\end{array}$ & $\begin{array}{l}\text { 1.Knowledge } \\
\text { provider } \\
\text { 2.Facilitator/ } \\
\text { scaffolder } \\
\text { 3.Sup. authority } \\
\text { figure } \\
\text { 4.Nurturer/cultivator } \\
\text { 5.Archetype of spirit } \\
\text { 6.Molder/craftperson }\end{array}$ & $\begin{array}{l}\text { 1. Knowledge } \\
\text { provider } \\
\text { 2. Facilitator/ } \\
\text { scaffolder }\end{array}$ & $\begin{array}{l}\text { Knowled. provider (29) } \\
\text { Facilitator/scaffol. (16) } \\
\text { Nurturer/cultivator (15) } \\
\text { Sup. authority figure (8) }\end{array}$ & $\begin{array}{l}87 \\
49 \\
29 \\
16\end{array}$ & $\begin{array}{c}\# 1 \text { in } 2 \text { studies } \\
\# 1 \text { in } 1 \text { study } \\
- \\
-\end{array}$ \\
\hline
\end{tabular}

*The research sample of Study VI includes ELT student teachers and EFL learners, separately.

To ensure better understandability of the data shown in Table 6, on a holistic and inferential basis, Figure 3 illustrates the teachers' emerging roles as metaphorically perceived by the teachers, students and learners.
Figure 3: Conceptual metaphor categories regarding Turkish EFL teachers' roles as perceived by the teachers, student teachers and learners

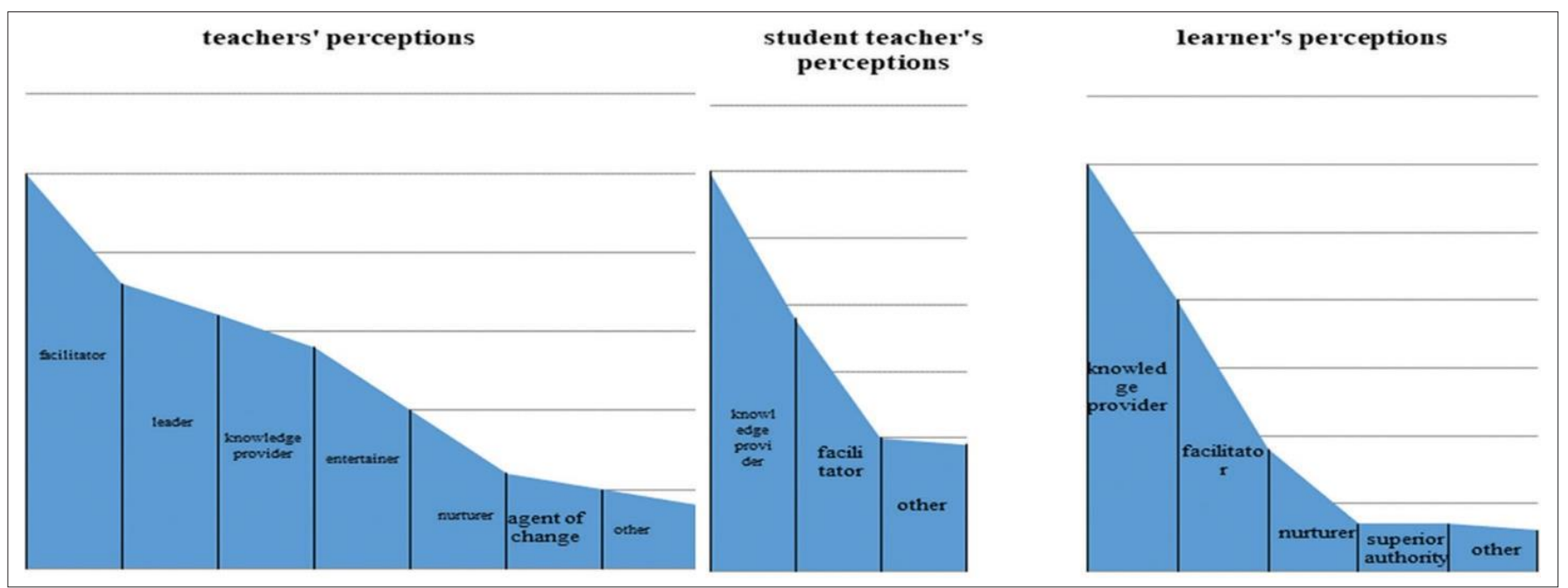


Considering the data presented in Table 6 , as reinforced by Figure 3, it can be inferred that the ELT student teachers and learners characterize Turkish EFL teachers with knowledge provider role primarily, followed by facilitator/ scaffolder role perception. Given the teachers' metaphorical conceptualizations, they tend to portray their roles as that of a facilitator/scaffolder most. In addition, they seem to assign the roles of cooperative/democratic leader, knowledge provider and entertainer for themselves substantially, in a descending order.

\section{DISCUSSION}

Through the meta-summary of metaphorical perceptions toward Turkish EFL teachers' roles, this study revealed the dominant roles associated with them, as well as the potential differences in these assigned roles as perceived by the teachers themselves, student teachers and learners. When the results of this meta-summary are handled in a holistic manner, Turkish EFL teachers are mostly identified in terms of knowledge provider, and then facilitator/scaffolder roles. While knowledge provider role was often represented with dictionary, book, light and ocean metaphors, facilitator/scaffolder role category often included metaphors such as coach, key, life coach, compass and light house. Other significant associations for the teachers' roles are that of a nurturer/ cultivator and archetype of spirit. Superior authority figure, molder and agent of change are the roles that are least associated with these teachers metaphorically.

When the emergent roles are analyzed with respect to different groups that produced metaphors for Turkish EFL teachers, it was understood that knowledge provider is by far the most defined role to characterize EFL teachers from the perspectives of student teachers and learners. This is followed by the role of a facilitator/scaffolder. While these are representatives of the overall tendency to label Turkish EFL teachers' roles, the teachers themselves vary in terms of the roles they assign to themselves. The teachers characterize themselves with facilitator/scaffolder role most, and this is followed by the roles of a leader, knowledge provider, and entertainer. This is where the teachers' metaphorical role attributions for themselves differ from those of ELT student teachers and learners. In a narrower sense, while for ELT students and English learners, their teachers are mainly knowledge providers, the teachers view themselves primarily as facilitators/scaffolders in language learning and teaching process.

Given these findings, it is necessary to distinguish between the main assigned roles (i.e. knowledge provider and facilitator/scaffolder) in terms of teachercentered and student-centered orientations to teaching (Kember, 1997). In line with the knowledge provider role, the behaviorist theory views knowledge as existing outside of people and independently of them, and therefore characterizes students as passive recipients of knowledge, and teachers as sources and transmitters of knowledge (Scheurman, 1998). On the other hand, a constructivist view of learning presents a student-centered framework, which sees knowledge as something created rather than received, and mediated by discourse rather than transferred by teacher talk (Holt-Reynolds, 2000). The latter notion conforms with teachers' facilitator/scaffolder roles, assigning them the role of stimulating the construction of knowledge, while expecting students to be active in the process of knowledge construction (Harris \& Alexander, 1998). Given these theoretical considerations for teaching, "it is noteworthy that constructivist approaches to teaching require teachers to reconceptualize their roles and develop new teaching roles to facilitate each student's way of perceiving, understanding and constructing new knowledge" (Sayar, 2014, p. 16-17).

\section{CONCLUSION AND SUGGESTIONS FOR FURTHER RESEARCH}

This study sought to provide an overarching understanding of the metaphorical conceptualizations concerning Turkish EFL teachers' roles. In so doing, meta-summary methodology was adopted by bringing together related research findings in the face of the inadequacy of individual metaphors in explaining the whole phenomenon (Saban, 2008). Similar meta-studies can be performed with the aim of drawing an inclusive portrait of metaphors for English language learners, English learning process, and the teaching of English. Last but not least, metaphor research needs to go beyond the simplistic "...is like...because..." elicitation task in data collection stages. This task should be accompanied by metaphor-eliciting essays, compositions, narratives and interviews to allow for the emergence of more detailed and reliable metaphors.

\section{REFERENCES}

Ahkemoğlu, H. (2011). A study on metaphorical perceptions of EFL learners regarding foreign language teacher. Master's thesis, Çukurova University, Institute of Social Sciences).

Akbari, M. (2013). Metaphors about EFL teachers' roles: A case of Iranian non-English-major students. IJELTS: International Journal of English Language \& Translation Studies 1(2), 100-112.

Aktekin, N. Ç. (2013). Revealing ESL teachers' and students' attitudes and beliefs through metaphors. Journal of Uludag University Faculty of Education, 26(2), 405-422.

Asmal1, M., \& Çelik, H. (2017). EFL teachers' conceptualizations of their roles through metaphor analysis. Journal of Language and Linguistic Studies, 13(2), 01-13.

Baş, M., \& Gezegin, B. B. (2015). Language learning as losing weight: Analysing students' metaphorical perceptions of English learning process. ProcediaSocial and Behavioral Sciences, 199, 317-324. 
Botha, E. (2009). Why metaphor matters in education. South African Journal of Education, 29(4), 431-444.

Brown, C. P., \& Lan, Y. C. (2015). A qualitative metasynthesis comparing US teachers' conceptions of school readiness prior to and after the implementation of NCLB. Teaching and Teacher Education, 45, 1-13.

Çalık, M., \& Sözbilir, M. (2014). Parameters of content analysis. Education and Science, 39(174), 33-38.

Çelik, H., \& Asmalı, M. (2017). In-service English teachers' conceptions about 'Learning' and 'Learner': Reflections from the shift in language teacher education. Kastamonu Education Journal, 25(6), 2465-2478.

Coşkun, A. (2015). Parents and young learners' metaphorical perceptions about learning English. Journal of Education and Training Studies, 3(5), 231-241.

Creswell, J. W., \& Poth, C. N. (2017). Qualitative inquiry and research design: Choosing among five approaches. Sage publications.

Dincer, A. (2017). EFL learners' beliefs about speaking English and being a good speaker: A metaphor analysis. Universal Journal of Educational Research, 5(1), 104-112.

Elkılıç, G., \& Aybirdi, N. (2016). Metaphorical perceptions of Turkish EFL instructors in relation to their students. The European Proceedings of Social \& Behavioural Sciences epsbs, 330-337.

Elkılıç, G., \& Bayrakçı, K. (2016). Metaphorical perceptions of the students in the department of translation and interpretation in relation to their English and French language instructors at Kafkas University, International Journal of Humanities and Social Science Invention, 5(11), 60-66.

Erkmen, B. (2010). Non-native novice EFL teachers' beliefs about teaching and learning. Doctoral dissertation, University of Nottingham.

Fang, S. U. (2015). College EFL Learners' metaphorical perceptions of English learning. The Journal of AsiaTEFL, 12(3), 61-79.

Fleener, M. J. (1995). A Study of preservice teachers' metaphors for the different roles of the mathematics teacher. Eric Document Reproduction Service No. ED389596.

Guerrero, M., \& Villamil, O. S. (2000). Exploring ESL teachers' roles through metaphor analysis. TESOL quarterly, 34(2), 341-351.

Halland, J. (2007). A thematic analysis of narratives of depression. University of Cape Town. South Africa. $\quad \operatorname{Re}$ trieved from http://www.psychology.uct.ac.za/sites/default/files/image_tool/images/117/Joni.Halland.pdf

Hamilton, E. R. (2016). Picture This: Multimodal representations of prospective teachers' metaphors about teachers and teaching. Teaching and Teacher Education, 55, 33-44.

Harris, K. R., \& Alexander, P. A. (1998). Integrated, constructivist education: Challenge and reality. Educational Psychology Review, 10(2), 115-127.

Holt-Reynolds, D. (2000). What does the teacher do?
Con- structivist pedagogies and prospective teachers' beliefs about the role of a teacher. Teaching and Teacher Edu-cation, 16(1), 21-32.

İnceçay, V. (2015). "The Foreign Language Classroom is Like an Airplane" metaphorical conceptualizations of teachers' beliefs. Turkish Online Journal of Qualitative Inquiry, 6(2), 74-96.

Kavanoz, S. (2016). Unveiling pre-service language teachers' conceptualizations of teachers of English through metaphors. Journal of Education and Training Studies, 4(10), 17-32.

Kember, D. (1997). A reconceptualisation of the research into university academics' conceptions of teaching. Learning and Instruction, 7(3), 255-275.

Kesen, A. (2010). Turkish EFL Learners' metaphors with respect to English language coursebooks. Novitas ROYAL, 4(1). 108-118.

Kesen, A. (2013). What lies beneath teacher beliefs? A study on metaphoric perceptions. Journal of Human Sciences, 10(1), 1491-1502.

Lakoff, G., \& Johnson, M. (1980). Metaphors we live by. Chicago. Chicago University.

Lakoff, G., \& Johnson, M. (2003). Metaphors we live by. $2^{\text {nd }}$. Lincoln, Y. S., \& Guba, E. G. (1985). Naturalistic inquiry (Vol. 75). Sage.

Major, C. H., \& Savin-Baden, M. (2010). An introduction to qualitative research synthesis: Managing the information explosion in social science research. New York: Routledge.

Marshall, H. H. (1990). Metaphors we learn by, Theory Into Practice, 29(2), 70-70, DOI: 10.1080/00405849009543434

Martínez, M. A., Sauleda, N., \& Huber, G. L. (2001). Metaphors as blueprints of thinking about teaching and learning. Teaching and Teacher education, 17(8), 965-977.

Munby, H., \& Russell, T. (1990). Metaphor in the study of teachers' professional knowledge. Theory Into Practice, 29(2), 116-121.

Nikitina, L., \& Furuoka, F. (2008). "A language teacher is like...": examining Malaysian students' perceptions of language teachers through metaphor analysis. Electronic Journal of Foreign Language Teaching, 5(2), 192-205.

Oktay, Y. B., \& Osam, Ü. V. (2013). Viewing foreign language teachers' roles through the eyes of teacher and students. Hacettepe University Journal of Education, 44, 249-261.

Ortony, A., \& Fainsilber, L. (1989). The role of metaphors in descriptions of emotions. In Yorick Wilks (Eds.), Theoretical issues in natural language processing (pp. 181184). Hillsdale, NJ: Erlbaum.

Oxford, R. T., S. Barcelos, A., Harrington, C., Lavine, R. Z., Saleh, A., \& Longhini, A. (1998). Clashing metaphors about classroom teachers: Toward a systematic typology for the language teaching field, System, 26(1), 3-50.

Özcan, M., Koçyiğit, M., Erdem, C. (2015). Üniversite hazırlık sınıfı öğrencilerinin üniversite, hazırlık Sınıfı, İngilizce dersi ve İngilizce öğretim elemanı hakkındaki metaforik algıları. 7. International Congress of Educational Research, 28-31.05.2015, Muğla Sitkı Koçman University. 
Perry, C., \& Cooper, M. (2001). Metaphors are good mirrors: reflecting on change for teacher educators. Reflective Practice, 2(1), 41-52.

Saban, A., Koçbeker, B. N., \& Saban, A. (2006). An investigation of the concept of teacher among prospective teachers through metaphor analysis. Educational Sciences: Theory \& Practice, 6(2), 509522.

Saban, A. (2008). Metaphors about school. Educational Administration: Theory and Practice, 55, 459-496.

Şahin, M., Seçer, Ş. Y., \& Erişen, Y. (2016). Perception of 'English' and motivation in learning English. Journal of Education and Training Studies, 4(9), 43-60.

Sandelowski, M., \& Barroso, J. (2007). Handbook for synthesizing qualitative research. Springer Publishing Company.

Sandelowski, M., Barroso, J., \& Voils, C. I. (2007). Using qualitative metasummary to synthesize qualitative and quantitative descriptive findings. Research in Nursing \& Health, 30(1), 99-111.

Sayar, E. (2014). Investigating EFL teachers' and their students' conceptions of professional teacher identity through metaphor analysis. Master's thesis, Abant İzzet Baysal University, Institute of Educational Sciences.

Scheurman, G. (1998). From behaviorist to constructivist teaching. Social Education, 62(1), 6-9.

Seferoğlu, G., Korkmazgil, S., \& Ölçü, Z. (2009). Gaining insights into teachers' ways of thinking via metaphors. Educational Studies, 35(3), 323-335.

Şimşek, M. R. (2014). A metaphor analysis of English teacher candidates' pre- and post-course beliefs about language and teaching. Dicle University Journal of Ziya Gökalp Faculty of Education, 22, 230-247.

Şimşek, M. R., \& Dündar, E. (2015). Metaphorical representations of a locally-produced English coursebook: Uncovering learner beliefs. Journal of International Social Research, 8(40), 586-594.

Spall, S. (1998). Peer debriefing in qualitative research: Emerging operational models. Qualitative Inquiry, $4(2), 280-292$.

Sumsion, J. (2003). Rereading metaphors as cultural texts: A case study of early childhood teacher attrition. The Australian Educational Researcher, 30(3), 67-87.

Tercan, G. (2015). Prospective English language teachers' metaphorical perceptions of a language teacher teaching English to young learners. Master's thesis, Çanakkale Onsekiz Mart University, Institute of Educational Sciences.

Tobin, K. (1990). Changing metaphors and beliefs: A master switch for teaching? Theory Into Practice, 29(2), 122-127.

Wan, W., Low, G. D., \& Li, M. (2011). From students' and teachers' perspectives: Metaphor analysis of beliefs about EFL teachers' roles. System, 39, 403415.

Willig, C. (2013). Introducing qualitative research in psychology. McGraw-Hill Education (UK).

Yalçın-Arslan, F., \& Cinkara, E. (2016). Examining
EFL teacher candidates' conceptions of English language teachers through metaphors. University of Gazian- tep Journal of Social Sciences, 15(4), 10951104. DOI:10.21547/jss.265494

Yeşilbursa, A. (2012). Using metaphor to explore the professional role identities of higher education English language instructors. Procedia-Social and Behavioral Sciences, 46, 468-472. 